\title{
Limited Trading of Emissions Permits as a Climate Cooperation Mechanism?
}

\section{US-China and EU-China Examples}

\author{
Claire Gavard ${ }^{\mathrm{a}, *}$, Niven Winchester ${ }^{\mathrm{b}}$ and Sergey Paltsev ${ }^{\mathrm{b}}$
}

${ }^{a}$ Centre for European Economic Research (ZEW), L7, 1, D-68161 Mannheim, Germany; gavard@zew.de.

b Joint Program on the Science and Policy of Global Change, Massachusetts Institute of Technology, 77 Massachusetts Ave, E19-411, Cambridge, MA 02139-4307, USA; niven@mit.edu,paltsev@mit.edu.

* Corresponding author, gavard@zew.de, Ph: +49.621.1235.208, Fax: +49.621.1235.226. 


\begin{abstract}
Recent multilateral climate negotiations have underlined the importance of international cooperation and the need for support from developed to developing countries to address climate change. This raises the question of whether carbon market linkages could be used as a cooperation mechanism. Policy discussions surrounding such linkages have indicated that, should they operate, a limit would be set on the amount of carbon permits that could be imported by developed regions from developing countries. This paper analyzes the impact of limited carbon trading between an ETS in the EU or the US and a carbon market covering Chinese electricity and energy intensive sectors using a global economy-wide model. We find that the limit results in different carbon prices between China and Europe or the US. Although the impact on low-carbon technologies in China is moderate, global emissions reductions are deeper than in the absence of international trading due to reduced carbon leakage. If China captures the rents associated with limited permit trading, we show that it is possible to find a limit threshold that makes both regions better off relative to carbon markets operating in isolation.
\end{abstract}

\title{
Keywords:
}

Sectoral agreements; emissions trading; China; electricity sector; climate policy; carbon leakage.

\section{INTRODUCTION}

Carbon markets are being developed around the world as policy instruments to reduce greenhouse gases emissions. For example, national or subnational carbon markets are operating in Europe, Japan, New Zealand, California, the Northeastern United States and Eastern Canada (Trotignon et al., 2011). ${ }^{1}$ Additionally, pilot schemes have been launched in several Chinese provinces and cities with the intention of implementing a national emissions trading system. ${ }^{2}$ Some interconnections between carbon markets already exist (e.g., between California and Québec) and these linkages may expand in the future.

\footnotetext{
${ }^{1}$ The EU ETS has been extensively analyzed. Among others, Ellerman and Buchner (2007) evaluated the first phase of the ETS. Ellerman and Buchner (2008) examine the extent of over-allocation of permit and emissions abatement that took place in the first phase of the scheme, and Hepburn et al. (2006) discusses the options for introducing auctioning in the second phase. More recently, Martin et al. (2013) analyze compensation rules aimed at reducing carbon leakage in trade exposed sectors. In the US, Chen et al. (2011) and Caron et al. (2015) examine the California's cap-and-trade program, and Sue Wing and Kolodziej (2008) examine leakage from the Regional Greenhouse Gas Initiative in the Northeastern. At the national level, Paltsev et al. (2009) estimate the impact of a potential carbon market on the US economy.

${ }^{2}$ Chinese pilot markets currently operate in Beijing, Tianjin, Shanghai, Chongqing, Hubei, Guangdong and Shenzhen.
} 
In parallel, the Paris Agreement adopted at the $21^{\text {st }}$ Conference of the Parties (COP21) of the United Nation Framework Convention on Climate Change (UNFCCC) stressed the importance of international cooperation, and in particular the need for support from developed to developed countries to address climate change. One mechanism that meets the dual objectives of cooperation and assistance is the linking of carbon markets in developed and developing regions. $^{3}$

To date, developing countries have been involved in carbon markets through the Clean Development Mechanism (CDM) defined in Article 12 of the Kyoto Protocol (UN, 1998). For each project approved by the CDM Executive Board, a certain amount of credits, called Certified Emission Reductions (CER) are issued. ${ }^{4}$ Many of these projects are renewable energy projects in India or China, e.g., the Huadian Fuqing Niutouwei wind power project in China. These CERs can be traded and sold in the carbon markets developed by more industrialized countries. Among these carbon markets, the EU Emissions Trading Scheme (ETS), launched in 2005, has been the largest one to accept CERs for compliance. Similarly, under the Joint Implementation mechanism (JI) defined in Article 6 of the Kyoto Protocol, Emissions Reduction Units (ERU) can be earned for projects occurring in Annex B countries and traded in other Annex B countries. $^{5}$

In earlier UNFCCC sessions, new market mechanisms have been considered to move away from the CDM to a wider approach. In the Durban COP in 2011, sectoral trading was one alternative mechanism proposed (EU, 2009). This instrument involves including a sector or sectors from one nation in the cap-and-trade system of another nation or group of nations (IEA, 2009b). For example, electricity sectors in China or India could be linked to the EU ETS. Such approaches have been widely discussed (Baron et al., 2008; Baron et al., 2009; CCAP, 2008; Bradley et al., 2007; ICC, 2008; IEA, 2006a, 2006b; IEA, 2007). Although they are less efficient than a global cap-and-trade system (Tirole, 2009), they are seen as a way to encourage participation in an international climate agreement (Sawa, 2010). As emissions reductions achieved through the CDM have been criticized (Schneider, 2007), there is a hope that a sectoral mechanism would achieve greater environmental benefits (IEA, 2005a; IEA, 2005b; IEA, 2006a, 2006b; Schneider and Cames, 2009a, Schneider and Cames, 2009b; Sterk, 2008) and take advantage of a wider set of abatement opportunities (CCAP, 2010).

Several previous studies have investigated the impact of sectoral trading. Hamdi-Cherif et al. (2010) analyzed sectoral trading between all developed countries and the electricity sector of developing countries. Gavard et al. (2011a) looked at the hypothetical US-China case, with trading between a national policy in the US and an electricity cap in China. These studies

\footnotetext{
${ }^{3}$ While "emission trading" is not explicitly mentioned in the Paris Agreement, it calls for "internationally transferred mitigation outcomes".

${ }^{4}$ Lecocq and Ambrosi (2007) presents the process through which CER units are issued and the sectors and developing countries in which most CDM projects take place.

${ }^{5}$ Annex B countries are countries with emissions reductions or limitation commitments under the Kyoto Protocol (UN, 1998).
} 
showed that, with unlimited sectoral trading, carbon prices in the two systems are equalized and a large proportion of the emissions reductions specified in the developed country are implemented in the developing country. Hence carbon price decreases in the developed country resulted in a partial reversal of the technological changes induced by carbon policies in the absence of sectoral trading. Conversely, sectoral trading induces greater adoption of low-carbon technologies in emerging regions. Previous studies also show that such policies lead to carbon leakage to the rest of the emerging country economy due to a reduction in fossil fuel prices. Gavard et al. (2011b) show that the European carbon price would decrease by more than $75 \%$ if there wasere unlimited sectoral trading between the EU ETS and Chinese electricity sector. This suggests that policy makers would limit the amount of permits that could be traded if such mechanisms were adopted, in the same way that caps are imposed on the volume of CERs and ERUs accepted for compliance in the EU ETS. ${ }^{6}$

The purpose of this paper is to quantify the emissions, energy and economic impacts of limited carbon trading between a developed and a developing country. Given the US-China joint statements on climate change (White House, 2014 and White House, 2015), and the EU ETS experience in accepting international credits, this paper evaluates, coupling between (1) a (hypothetical) US ETS and a carbon market covering electricity and energy intensive sectors in China, and (2) the EU ETS and the same partial carbon market in China, and (3) a trilateral USEU-China carbon market. The analysis considers the time period 2020-2030 in three further sections. Section 2 describes relevant policies, the modeling framework and the scenarios considered. Section 3 presents the results. Section 4 concludes.

\section{MODELING FRAMEWORK}

The analysis in this paper extends the MIT Emissions Prediction and Policy Analysis (EPPA) model. Policies represented in this model include national ETSs, the use of offsets through the CDM, and sectoral trading.

\subsection{The EPPA Model}

The EPPA model is a recursive-dynamic, multi-region computable general equilibrium model (Paltsev, 2005). The model is designed to assess the impact of energy and environmental policies on emissions and economic activity. Version 5 of the model is calibrated to 2004 economic data and is solved through time by specifying exogenous population and labor productivity increases, for 2005 and for five-year increments thereafter. As indicated in Table 1, 16 countries or regions are represented. For each country or region, fourteen production sectors are defined: five energy sectors (coal, crude oil, refined oil, gas and electricity), three agricultural sectors (crops, livestock and forestry), and five other non-energy sectors (energy-intensive industry, transport, food products, services and other industries). Factors of production include capital, labor, land

\footnotetext{
${ }^{6}$ In related literature, Massetti and Tavoni (2012) analyze the potential response of Asian economies to global or regional cap-and-trade schemes.
} 
and resources specific to energy production. There is a single representative utility-maximizing agent in each region that derives income from factor payments and emissions permits and allocates expenditures across goods and investment. A government sector collects revenue from taxes and purchases goods and services. Government deficits and surpluses are passed to consumers as lump sum transfers. Final demand separately identifies household transportation and other household demand.

Production sectors are represented by nested constant elasticity of substitution production functions. Production sector inputs include primary factors (labor, capital and energy resources) and intermediate inputs. Goods are traded internationally and differentiated by region of origin following an Armington assumption (Armington, 1969), except crude oil which is considered as a homogenous good.

In the model, electricity can be generated from traditional technologies (coal, gas, oil, refined oil, hydro and nuclear) and advanced technologies. Advanced technologies include solar, wind, biomass, natural gas combined cycle, natural gas with carbon capture, integrated gasification combined cycle with carbon capture, advanced nuclear, wind with biomass backup, and wind with gas backup. There also are four technologies that produce substitutes for energy commodities: shale oil and hydrogen are substitutes for crude oil, synthetic gas from coal is a substitute for natural gas and liquids from biomass is a substitute for refined oil. The period in which advanced technologies become available reflects assumptions about technological developments. When available, advanced technologies compete with traditional energy technologies on an economic basis.

The model projects emissions of GHGs (carbon dioxide, methane, nitrous oxide, perfluorocarbons, hydrofluorocarbons and sulfur hexafluoride) and urban gases that also impact climate (sulfur dioxide, carbon monoxide, nitrogen oxides, non-methane volatile organic compounds, ammonia, black carbon and organic carbon).

Version 5 of the EPPA model is calibrated using economic data from Version 7 of the Global Trade Analysis Project (GTAP) database (Narayanan and Walmsley, 2008) and energy data from the International Energy Agency. The model is coded using the General Algebraic Modeling System (GAMS) and the Mathematical Programming System for General Equilibrium analysis (MPSGE) modeling language (Rutherford, 1995). 
Table 1. EPPA model aggregation.

\begin{tabular}{|c|c|c|}
\hline Countries or Regions & Sectors & Factors \\
\hline Developed countries & Non-Energy Sectors & Capital \\
\hline United States (USA) & Crops (CROP) & Labor \\
\hline Canada (CAN) & Livestock (LIVE) & Crude Oil Resources \\
\hline Japan (JPN) & Forestry (FORS) & Natural Gas Resources \\
\hline Australia-New Zealand (ANZ) & Food Products (FOOD) & Coal Resources \\
\hline \multirow[t]{2}{*}{ European Union (EUR) } & Energy-Intensive Industry (EINT) & Shale Oil Resources \\
\hline & Transport (TRAN) & Nuclear Resources \\
\hline Developing countries & Services (SERV) & Hydro Resources \\
\hline Mexico (MEX) & Other Industry (OTHR) & Wind Resources \\
\hline $\begin{array}{l}\text { Rest of Europe and Central Asia } \\
\text { (ROE) }\end{array}$ & & Solar Resources \\
\hline East Asia (ASI) & Energy Supply and Conversion & Land \\
\hline China $(\mathrm{CHN})$ & Electric Generation (ELEC) & \\
\hline India (IND) & Conventional Fossil & \\
\hline Brazil (BRA) & Hydro & \\
\hline Africa (AFR) & Nuclear & \\
\hline Middle East (MES) & Wind & \\
\hline Rest of Latin America (LAM) & Solar & \\
\hline Rest of Asia (REA) & Biomass (BIO) & \\
\hline \multirow[t]{13}{*}{ Russia (RUS) } & Advanced Gas (NGCC) & \\
\hline & Advanced Gas with CCS (NGCAP) & \\
\hline & Advanced Coal with CCS (IGCAP) & \\
\hline & $\begin{array}{l}\text { Advanced Nuclear (ADV-NUCL) } \\
\text { Wind with Biomass Backup } \\
\text { (WINDBIO) }\end{array}$ & \\
\hline & Wind with Gas Backup (WINDGAS) & \\
\hline & Fuels & \\
\hline & Coal (COAL) & \\
\hline & Crude oil (OIL), Refined Oil (ROIL) & \\
\hline & Natural Gas (GAS), & \\
\hline & Shale Oil (SYNF-OIL) & \\
\hline & Gas from Coal (SYNF-GAS) & \\
\hline & Liquids from Biomass (BIO-OIL) & \\
\hline & Hydrogen $\left(\mathrm{H}_{2}\right)$ & \\
\hline
\end{tabular}

\subsection{Limited Sectoral Trading of Emissions Permits}

Climate policy instruments in EPPA include emissions constraints, carbon taxes, energy taxes and technology regulations such as renewable portfolio standards. When there are emissions 
constraints under existing model functionality, permits may be either: (i) not tradable across sectors or regions, resulting in sector-specific permit prices in each region, (ii) tradable across sectors within regions but not across regions, resulting in region-specific permit prices, or (iii) tradable across sectors and regions, resulting in an international permit price. Modeling limited sectoral trading requires extending the model to allow trade between international permits and sector-specific permits an including an option to cap the amount of permits that can be traded.

A trade certificate system is introduced to set the limit on the amount of sectoral permits that can be imported from the developing country (e.g., China) to more industrialized countries (e.g., the EU ETS). The number of certificates issued is a fraction, $\alpha$, of the total amount of permits allocated in developed countries' carbon markets. Each permit exported from developing to developed regions requires a trade certificate, which limits the number of permits imported to $\alpha$ multiplied by the number of permits issued in developed regions. The revenue from the certificates is distributed either to the importer or exporter of permits, and will ultimately depend on how the policy is designed. In the model, alternative revenue allocations are considered by endowing certificates to either China or the developed region that it is trading with. As a consequence, the impact of the carbon market linkage on the welfare in the countries involved depends on this allocation choice, as discussed in the results presented in Section 3.

\subsection{Emissions Trading Schemes and Long-Term mitigation Objectives in Europe, China and the US}

For the COP21 in Paris, Europe, China and the US reaffirmed their long-term emissions reduction objectives in their respective Intended Nationally Determined Contributions (INDC). ${ }^{7}$ The US announced target is a 26 to $28 \%$ reduction of greenhouse gases emissions by 2025 below the 2005 level. For China, the goal for 2030 is a 60 to $65 \%$ reduction in carbon intensity below 2005 its level. ${ }^{8}$ Among the measures taken to achieve this objective, the development of an ETS at the national level that would likely cover electricity and energy-intensive industries was explicitly mentioned. In Europe, the 2030 aim is a 40\% emissions reduction below 1990 levels, as decided under the 2030 climate and energy framework and in line with the longer term $80 \%$ reduction objective stated in the 2050 roadmap.

The EU ETS is a key instrument for reducing European industrial greenhouse gas emissions. Started in 2005, it now covers more than 11,000 power stations and industrial plants in 31 countries. ${ }^{9}$ Credits from CDM and JI are accepted for compliance in the EU ETS under a specific limit. For Phase II of the scheme (2008-2012), this limit was $13 \%$ of the total amount of EU allowances. Some organizations estimate that 1.6 to 1.7 billion tons of credits could be used in Phase II and III combined (ICAP, 2016). Banking and borrowing is allowed within each phase.

\footnotetext{
${ }^{7}$ After Paris Agreement INDCs are converted to Nationally Determined Contributions (NDC). We keep the abbreviation INDC in our study to reflect the contributions.

${ }^{8}$ Zhang et al. (2014) examines the feasibility of emissions reduction pathways for China for the 2020-2050 timeframe.

${ }^{9}$ In addition to the EU Member States, Iceland, Norway and Liechtenstein also participate in the EU ETS.
} 
It is currently uncertain how the US will meet its INDC pledged at the Paris agreement. The Clean Power Plan (EPA, 2015), the current centerpiece of climate policy in the US, was put on hold by the Supreme Court in February 2016. Furthermore, the Clean Power Plan is only a first step in abating emissions. To meet its Paris commitments, it is highly likely that the US will have to implement policies on the electricity and other energy-intensive industries. In China, as the objective is expressed in terms of emissions intensity, there remains some uncertainty on the exact emissions path that this corresponds to.

In this analysis, the EU ETS is modeled as a carbon market covering the EU electricity and energy-intensive sectors. The emissions constraint imposed on these sectors is in line with the official EU ETS objectives: a 21\% reduction by 2020 below 2005, and a 43\% reduction by 2030 . Banking of allowances is modeled by specifying a carbon price in the base period that grows at an assumed discount rate of $5 \%$ per year. ${ }^{10}$ The base period carbon price is chosen to target cumulative emissions specified by the cap. In the modeling exercise, no distinction is made between Phase III (2013-2020) and Phase IV (2021-2028) of the EU ETS. We assume that the aviation sector has to buy some allowances in the general ETS even if this is partly compensated by the use of offsets (CDM and JI credits) as explained in Appendix. Similarly, we simulate an ETS covering the US electricity and energy intensive industries, with an emissions reduction constraint of $16 \%$ by 2020 below 2005 levels and of $29 \%$ by 2030 . We also allow banking of emissions permits for the whole time period, so the period-by-period emissions caps are converted to a cumulative emissions cap between 2020 and 2030. For China, we translate the economy wide carbon intensity objectives of Chinese INDC into ETS targets of a $70 \%$ increase in emissions by 2020 above the 2005 level and a $109 \%$ increase in 2030.

\subsection{Scenarios}

Nine core scenarios are used to analyze the impact of carbon trading with a limit on the amount of permits that can be exchanged, as summarized in Table 2. In the NO-POLICY scenario, no emissions constraints are imposed. In the CHN-ETS scenario, emissions from Chinese electricity and energy intensive sectors are capped from 2020 to 2030 in a way that is consistent with the emissions intensity objectives announced by China in the last years: the emissions targets discussed in Section 2.5 are simulated by imposing caps that reduce emissions by $17 \%$ in 2020 and $25 \%$ in 2030, relative to the NO-POLICY case. In the EU-ETS scenario, emissions from the European power and energy intensive sectors are capped at a level that takes account of the official EU ETS objectives and the use of CDM and JI credits as well as emissions targets specified for aviation and other EU ETS sectors, as outlined in the previous section. In the

\footnotetext{
${ }^{10}$ As the EPPA model is recursive dynamic, rather than including an endogenous interest rate that equates savings and investment, savings enters each representative household's utility function as a proxy for future consumption. In the absence of an interest rate, we assume an exogenous discount rate of 5\% in each region. This approach is consistent with other studies built on recursive dynamic models - see for example, Paltsev et al. (2009)
} 
US-ETS scenario, emissions from the power and energy intensive industries are capped at a level consistent with the emissions reductions objectives announced by the US in its INDC as explained in section 2.3. These commitments correspond to cumulative emissions reductions of 13 billion tons between 2015 and 2030 .

Table 2. Scenarios summary.

\begin{tabular}{|c|c|c|}
\hline Scenarios & $\begin{array}{l}\text { Carbon constraint on emissions from electricity and } \\
\text { energy-intensive sectors }\end{array}$ & $\begin{array}{l}\text { International } \\
\text { trading }\end{array}$ \\
\hline NO-POLICY & None & None \\
\hline CHN-ETS & $\begin{array}{l}17 \% \text { reduction in } 2020 \text { and } 25 \% \text { in } 2030 \text { compared to the } \\
\text { NO-POLICY scenario }\end{array}$ & None \\
\hline EU-ETS & $\begin{array}{l}21 \% \text { reduction by } 2020 \text { and } 43 \% \text { by } 2030 \text { compared to } \\
2005 \text { levels }\end{array}$ & None \\
\hline US-ETS & $\begin{array}{l}16 \% \text { reduction by } 2020 \text { and } 29 \% \text { by } 2030 \text { compared to } \\
2005 \text { levels }\end{array}$ & None \\
\hline EU-CHN-TRADE & As in CHN-ETS for China and EU-ETS for the EU & $\begin{array}{l}\text { Unlimited between China } \\
\text { and the EU }\end{array}$ \\
\hline EU-CHN-LIMIT & As in CHN-ETS for China and EU-ETS for the EU & $\begin{array}{l}\text { Limited between China } \\
\text { to the EU }\end{array}$ \\
\hline US-CHN-TRADE & As in CHN-ETS for China and US-ETS for the US & $\begin{array}{l}\text { Unlimited between China } \\
\text { and the US }\end{array}$ \\
\hline US-CHN-LIMIT & As in CHN-ETS for China and US-ETS for the US & $\begin{array}{l}\text { Limited between China } \\
\text { and the US }\end{array}$ \\
\hline $\begin{array}{l}\text { EU-US-CHN- } \\
\text { TRADE }\end{array}$ & $\begin{array}{l}\text { As in CHN-ETS for China, US-ETS for the US, and EU-ETS } \\
\text { for the EU }\end{array}$ & $\begin{array}{l}\text { Unlimited between } \\
\text { China, the EU and the } \\
\text { US }\end{array}$ \\
\hline
\end{tabular}

In the EU-CHN-TRADE scenario, carbon trading is allowed between the EU and Chinese ETS from 2020 onwards without any limit on the amount of permits traded. Similarly, for the US-CHN-TRADE scenario, emissions permits are exchanged between the US and China ETSs from 2020 onwards. In the EU-CHN-LIMIT scenario, carbon trading is allowed but the amount of carbon permits that can be imported from China to the EU ETS for each time period is limited to $10 \%$ of the total amount of European allowances for this time period $(\alpha=0.1)$. Given the constraint imposed on the EU ETS sectors, this fraction limits trade of certificates to 151, 130 and 110 million respectively in 2020, 2025 and 2030. In the US-CHN-LIMIT scenario, the amount of permits that can be imported from China to the US ETS is similarly limited to $10 \%$ of the US cap for each time period, which corresponds to a limit of 247, 232 and 209 respectively in 2020, 2025 and 2030. Finally, in the EU-US-CHN-TRADE scenario, we simulate a coupling between the three regional carbon markets considered in this study.

In alternative variants of the US-CHN-LIMIT and EU-CHN-LIMIT scenarios, we consider limits of $5 \%, 10 \%$ and $20 \%$. We assign the certificates revenue to the EU or the US in the core simulations. Alternative allocations of the certificate revenue are considered in additional simulations, in particular for the welfare analysis. 


\section{RESULTS AND DISCUSSION}

\subsection{Emissions Transfers and Carbon Prices}

Unlimited sectoral trading leads to a carbon price equalization between the two regions involved. Under limited sectoral trading, as long as the limit is binding, carbon prices in the two regions are not equalized and the difference in prices in the two regions depends on $\alpha$.

Emissions from the ETS covered sectors in each region are presented in Figure 1, and carbon prices in each region are displayed in Figure 2.
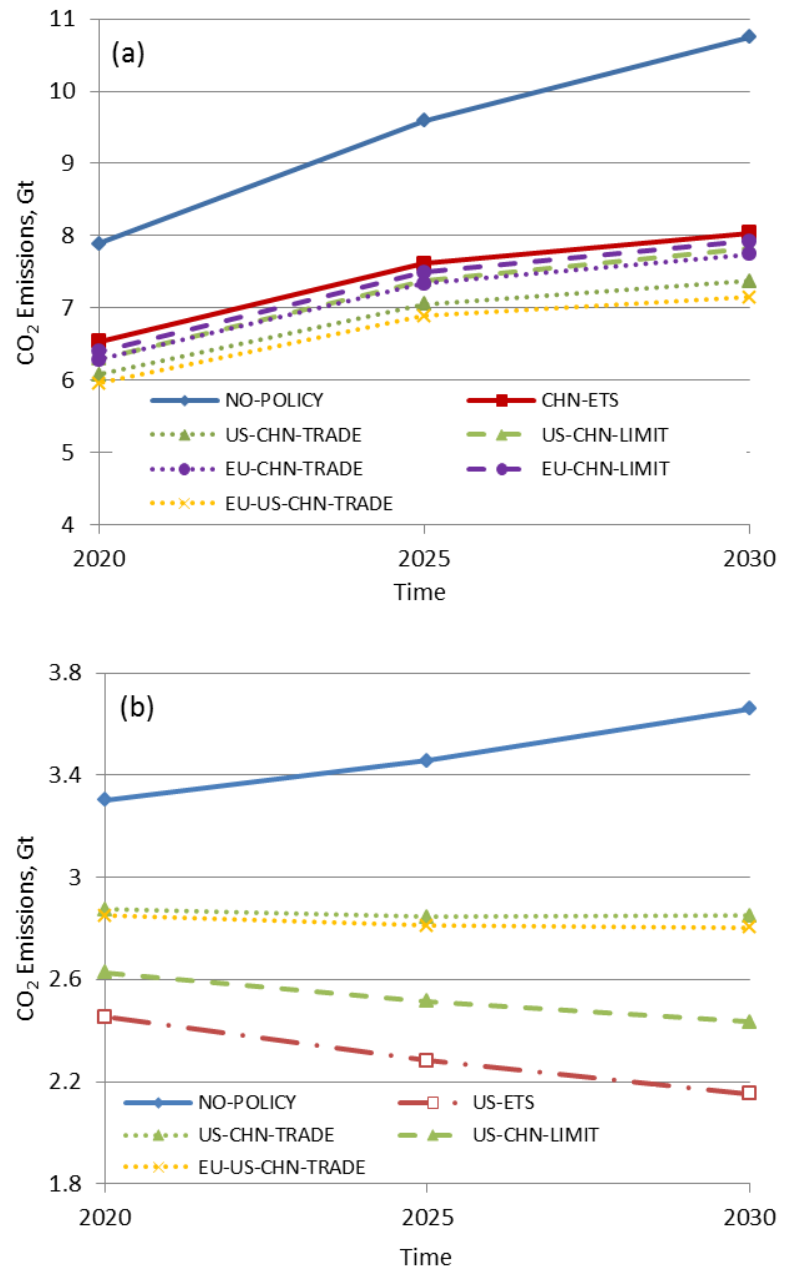

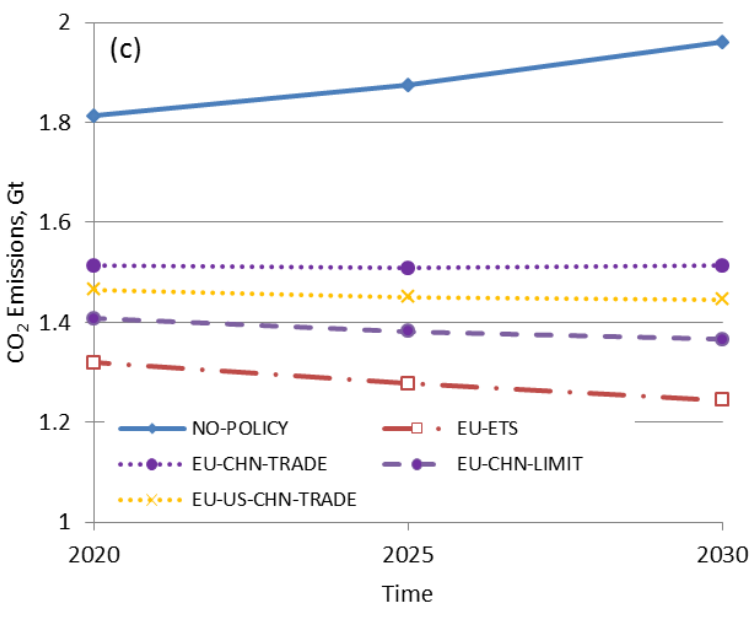

Figure 1. $\mathrm{CO}_{2}$ emissions from (a) the Chinese, (b) US and (c) EU ETS sectors. 

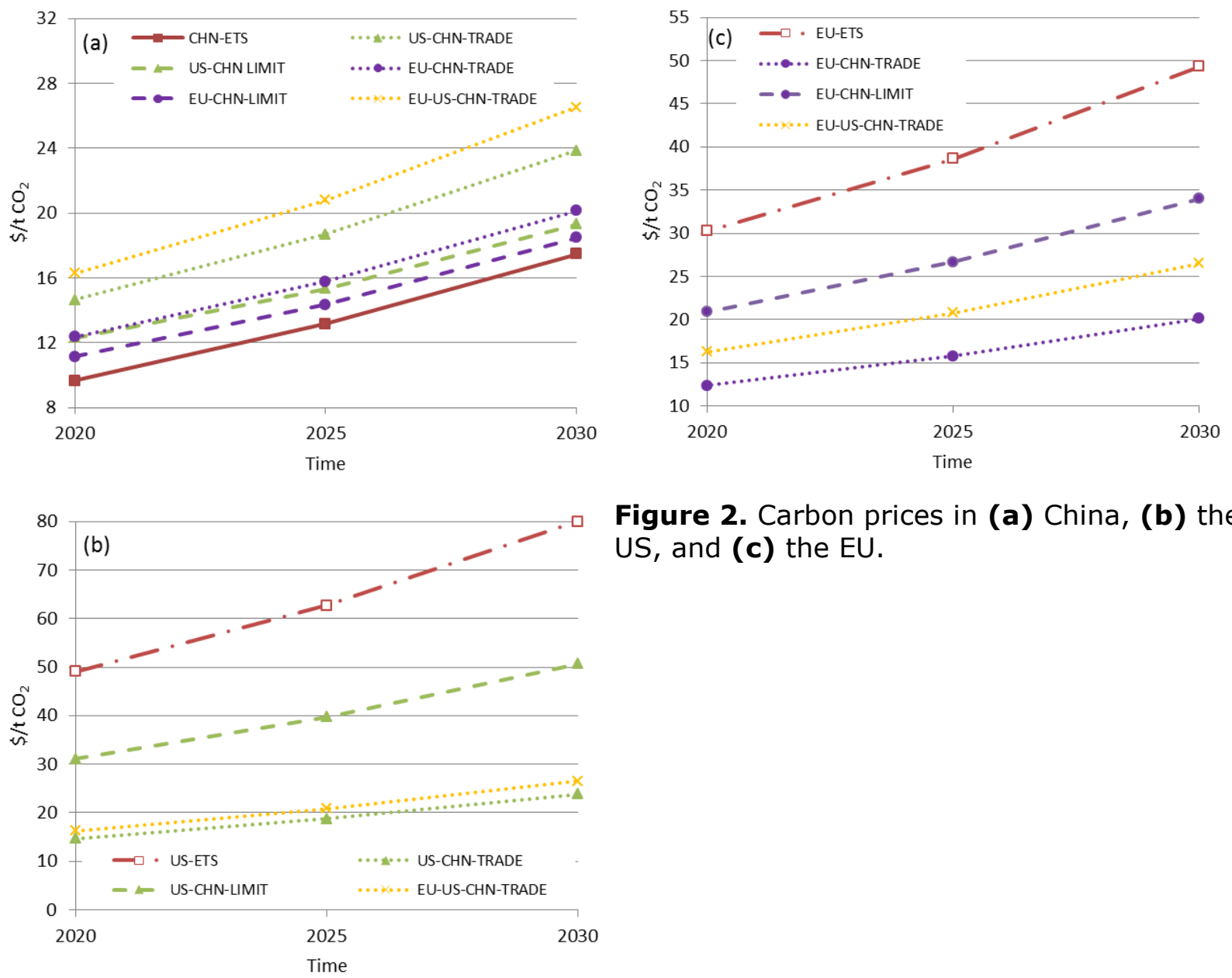

Figure 2. Carbon prices in (a) China, (b) the US, and (c) the EU.

Under the ETS constraint and in the absence of carbon trading with other countries, the emissions of Chinese power and energy intensive industries are 8.04 billion tons in 2030 (Figure 1a), i.e. 2.71 billion tons less than NO-POLICY emissions, and the corresponding carbon price $\$ 17.5 / \mathrm{tCO}_{2}$ (Figure 2a). If the US ETS is not coupled with the Chinese ETS, the US carbon price is $\$ 80 / \mathrm{tCO}_{2}$ in 2030 (Figure 2b) and the emissions covered by the US ETS amount to 2.15 billion tons in 2030, compared to 3.66 in the NO-POLICY scenario (Figure 1b). If unlimited sectoral trading is allowed between the two regions (US-CHN-TRADE), Chinese carbon permits corresponding to 663 million tons $\mathrm{CO}_{2}$ are exported to the US and the carbon price is equalized across the two systems at $\$ 23.9 / \mathrm{tCO}_{2}$ in 2030 . Emissions from the sectors covered by the US ETS are 2.85 billion tons while those from the Chinese ETS sectors are 7.37 billion tons in 2030. ${ }^{11}$

11 The amount of permits transferred in 2030 is the difference between Chinese ETS sectors emissions in the CHNETS and the US-CHN-TRADE scenarios in 2030. It is not equal to the difference between US emissions specified under the US ETS and the US-CHN-TRADE scenario in 2030, as assumed banking of allowances allows US agents to fulfill part of their 2030 emissions reductions obligations in previous periods. 
In the US-CHN-LIMIT scenario, imports of Chinese permits cannot exceed $10 \%$ of the number of permits issued under the US-ETS for each time period. This limit is 158 million in 2030. In this scenario, Chinese emissions are equal to 7.83 billion tons of $\mathrm{CO}_{2}$, while US emissions are 2.43 billion tons in 2030 . Carbon prices $\left(\$ 50.6 / \mathrm{tCO}_{2}\right.$ in the US and $\$ 19.3 / \mathrm{tCO}_{2}$ in China in 2030) are not equalized in the two regions.

In the case of unlimited carbon trading between the EU and China ETS, Chinese carbon permits corresponding to 296 million tons $\mathrm{CO}_{2}$ are exported to Europe (Figure 1c). EU and China carbon prices are equalized at $\$ 20.1 / \mathrm{tCO} 2$, which corresponds to a $60 \%$ drop in the EU carbon price (from $\$ 49.3 / \mathrm{tCO}_{2}$ in the EU-ETS scenario), as shown in Figure 2c. If a limit is set on the emissions permits that can be exported from China to the EU, the EU carbon price reduction is $30 \%$, while the Chinese carbon price is $\$ 18.5 / \mathrm{tCO}_{2}$.

In the case of a trilateral market (EU-US-CHN-TRADE), relative to the bilateral cases, the carbon price is higher (26.5\$/t in 2030) and emissions reductions in each regions are deeper. This is understandable as the carbon price in the EU-ETS case is greater than in the US-CHN-TRADE scenario and, symmetrically, the carbon price in the US-ETS scenario is higher than in the EUCHN-TRADE case.

Carbon prices and the volume of permits transferred vary with $\alpha$. The stricter the limit, the lower the amount of permits that are transferred from China to the US or the EU, and the larger the price difference between the two regions as reported in Table 3. In the US-China case, when $\alpha=0.05$, the volume of permits traded is 104 million tons in 2030, the carbon price is $\$ 18.5 / \mathrm{tCO}_{2}$ in China and $\$ 64.4 / \mathrm{tCO}_{2}$ in the US. In comparison, when $\alpha=0.2$, the volume of emission permits transferred is 418 million tons and the 2030 carbon price is $\$ 21 / \mathrm{tCO}_{2}$ in China and $\$ 30.4 / \mathrm{CO}_{2}$ in the US. Under unlimited sectoral trading, the US carbon price decreases by $70 \%$ and under limited trading, this reduction is $36 \%$ if $\alpha=0.1$ and $19 \%$ if $\alpha=0.05$.

Comparable effects are observed in the EU-China case. For a limit $\alpha=0.05,55$ million tons of $\mathrm{CO}_{2}$ permits are transferred from Europe to China and the EU carbon price is reduced by $16 \%$ compared to the EU-ETS scenario. For a limit $\alpha=0.2$, the volume of permits transferred from China to the EU corresponds to 219 million tons and the European price decreases by $54 \%$. 
Table 3. Carbon prices and volume of permits transferred in 2030 in the cases of US-China and EU-China carbon trading.

\begin{tabular}{|c|c|c|c|}
\hline & $\begin{array}{l}\text { Volume of Permits } \\
\text { Transferred }\left(\mathrm{Mt} \mathrm{CO}_{2}\right)\end{array}$ & $\begin{array}{l}\text { Chinese Carbon } \\
\text { Price }(\$ / \mathrm{t} \mathrm{CO})\end{array}$ & $\begin{array}{c}\text { US or EU } \\
\text { Carbon Price } \\
\left(\$ / t \mathrm{CO}_{2}\right)\end{array}$ \\
\hline CHN-ETS & - & 17.47 & - \\
\hline US-ETS & - & - & 80.0 \\
\hline $\begin{array}{l}\text { US-CHN-LIMIT, } \\
\alpha=0.05\end{array}$ & 104 & 18.5 & 64.4 \\
\hline $\begin{array}{l}\text { US-CHN-LIMIT, } \\
\alpha=0.1\end{array}$ & 209 & 19.3 & 50.6 \\
\hline $\begin{array}{l}\text { US-CHN-LIMIT, } \\
\alpha=0.15\end{array}$ & 313 & 20.1 & 39.5 \\
\hline $\begin{array}{l}\text { US-CHN-LIMIT, } \\
\alpha=0.2\end{array}$ & 418 & 21.0 & 30.4 \\
\hline US-CHN-TRADE & 663 & 23.9 & 23.9 \\
\hline EU-ETS & - & - & 49.3 \\
\hline $\begin{array}{l}\text { EU-CHN-LIMIT, } \\
\alpha=0.05\end{array}$ & 55 & 18.1 & 41.4 \\
\hline $\begin{array}{c}\text { EU-CHN-LIMIT, } \\
\alpha=0.1\end{array}$ & 110 & 18.5 & 34.0 \\
\hline $\begin{array}{l}\text { EU-CHN-LIMIT, } \\
\alpha=0.15\end{array}$ & 164 & 18.9 & 28.1 \\
\hline $\begin{array}{c}\text { EU-CHN-LIMIT, } \\
\alpha=0.2\end{array}$ & 219 & 19.3 & 22.7 \\
\hline EU-CHN-TRADE & 296 & 20.1 & 20.1 \\
\hline EU-US-CHN-TRADE & 886 & 26.5 & 26.5 \\
\hline
\end{tabular}

\subsection{Electricity Generation Profiles}

Carbon emissions constraints in China, the US and Europe change electricity generation profiles in these regions. While carbon trading between the two regions only implies a transfer of emissions, the impact on low carbon technologies in China is not the same as in Europe or the US due to differences in abatement cost. Figures 3, 4 and 5 present electricity generation in China, the US and the EU in all scenarios (for limited emissions trading cases, $\alpha$ is equal to 0.1). 


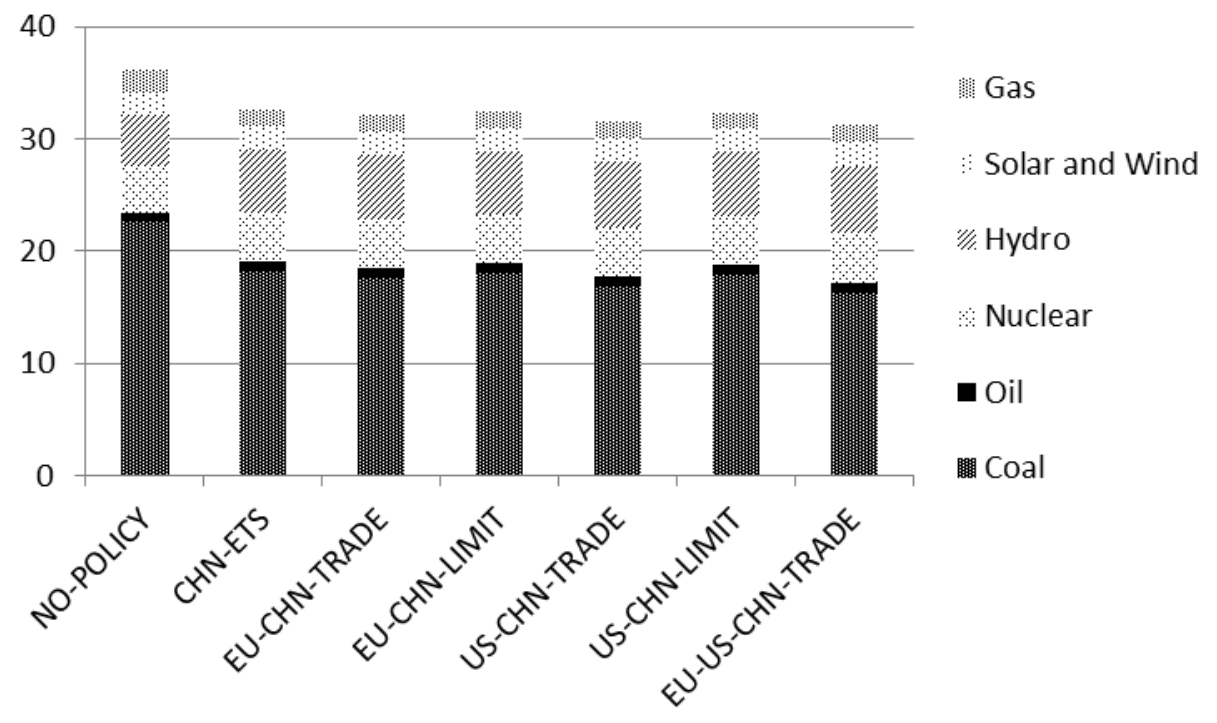

Figure 3. Electricity generation in China in 2030 (EJ).

In China, unlimited sectoral trading enhances the changes induced by the China ETS on the electricity sector. For example, electricity production from coal decreases by $7.5 \%$ in the USCHN-TRADE scenario relative to the CHN-ETS scenario. Electricity production from lowcarbon technologies is also impacted: in the US-CHN-TRADE scenario, relative to the ChinaCap scenario, electricity production from nuclear energy increases by $1.2 \%$, hydropower increases by $5.2 \%$, and wind and solar power increase by $3.4 \%$. The price of electricity increases by $16 \%$ in the US-CHN-TRADE scenario, which decreases demand and ultimately production by $3.2 \%$ compared to the CHN-ETS scenario. When sectoral trading is limited $(\alpha=0.1)$, these effects are smaller: relative to the CHN-ETS scenario, the electricity price increases by $1.8 \%$ and the total amount of electricity generated decreases by $0.9 \%$. The total amount of electricity produced in the US-CHN-TRADE scenario is 32.35 exajoules (EJ), out of which $12.10 \mathrm{EJ}$ from low carbon technologies, compared to a total of $32.64 \mathrm{EJ}$ including $12.04 \mathrm{EJ}$ from low carbon technologies in the CHN-ETS scenario. In the EU-US-CHN-TRADE scenario, the total amount of electricity produced is $31.19 \mathrm{EJ}$, with $12.57 \mathrm{EJ}$ from (combined) solar, wind, nuclear and hydropower. 


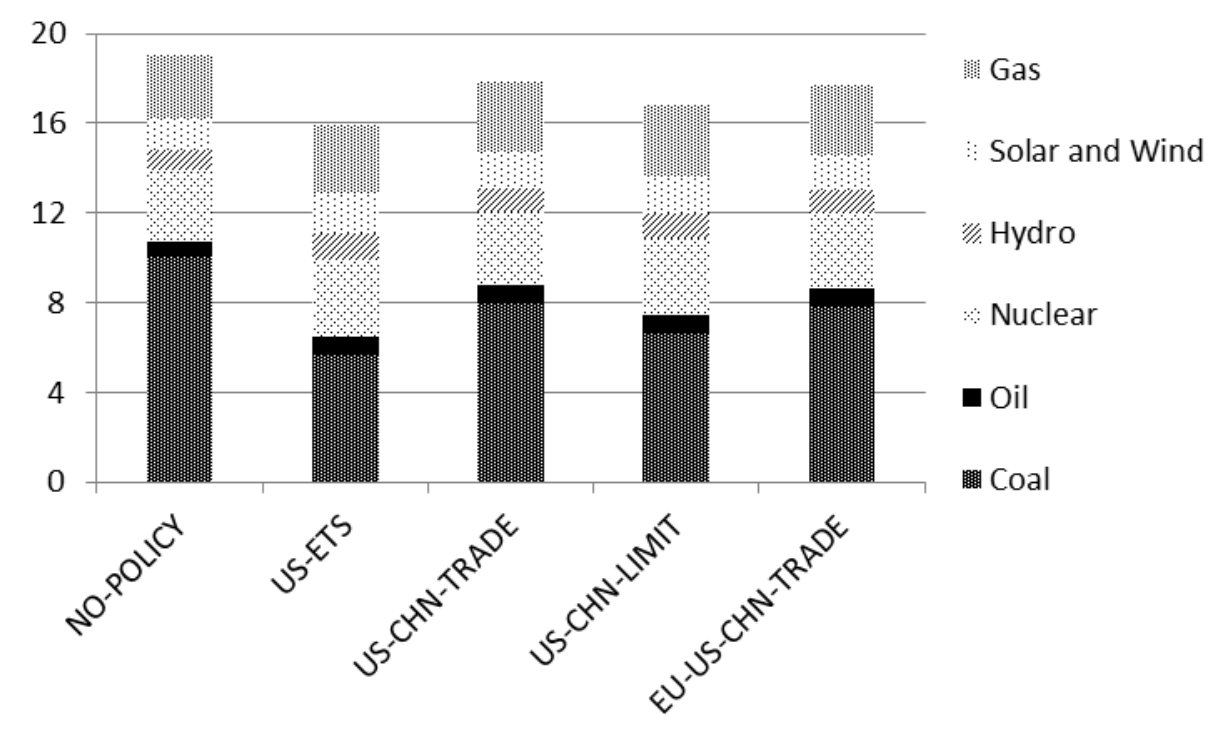

Figure 4. Electricity generation the US in 2030 (EJ).

In the US, unlimited sectoral trading partially reverses technological changes induced by the US ETS. Setting a limit on the amount of carbon permits that can be imported from China to the US reduces this effect. For example, in comparison to the US-ETS scenario, electricity production from coal increases by $40.4 \%$ in the US-CHN-TRADE scenario, by $37.8 \%$ in the EUUS-CHN-TRADE case, and by $16.9 \%$ in the US-CHN-LIMIT scenario. Additionally there is greater generation from low-carbon technologies in the US-CHN-LIMIT scenario than the USCHN-TRADE scenario: nuclear power production increases by $1 \%$, hydropower production increases by $8.6 \%$, and solar and wind power production increase by $6.3 \%$.

In the case of carbon trading between the EU and China, we observe comparable results. Unlimited imports of Chinese emissions permits to Europe induces an electricity price increase of $7.2 \%$ in China. This is associated with a reduction of $1.4 \%$ in the total amount of power produced domestically and an increase in generation from low- carbon technologies of $1.4 \%$ $(0.16 \mathrm{EJ})$. If carbon trading between the EU and China is limited, these effects are reduced. Relative to when there is unrestricted trade in permits, limited sectoral trading induces an increase of $2.8 \%$ in the price of electricity, a $0.47 \%$ reduction in total power production in China, and a $0.5 \%$ increase in generation from low-carbon technologies $(0.06 \mathrm{EJ})$. 


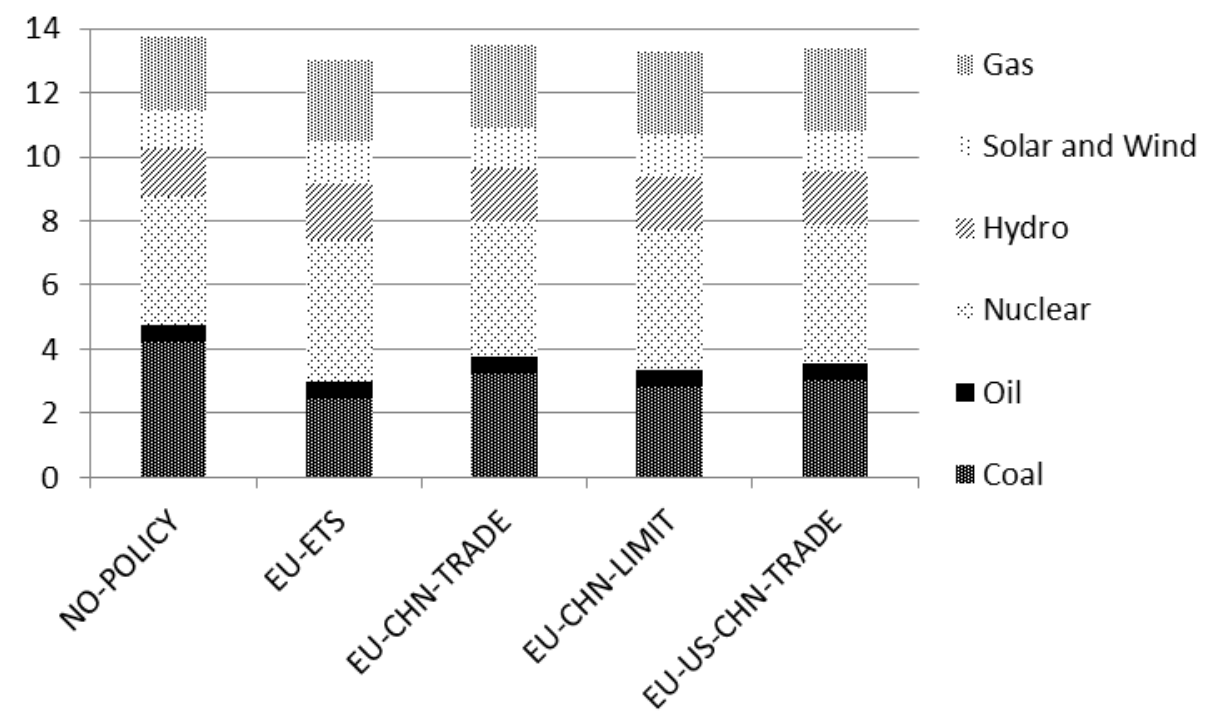

Figure 5. Electricity generation in the EU in 2030 (EJ).

In Europe, unlimited carbon trading with China reduces power generation technologies from low-carbon technologies by $4.7 \%$ ( $0.35 \mathrm{EJ})$ compared to EU-ETS scenario. In the case of a trilateral market, this reduction is $3.5 \%$ ( $0.26 \mathrm{EJ})$. In the case of limited trading, this decrease is $2.2 \%$.

In summary, unlimited sectoral trading between the EU or US ETS and the Chinese carbon market would enhance the development of low-carbon electricity technologies in China relative to an isolated China ETS and also decrease the total amount of electricity produced. In Europe, or the US, this would partly reverse deployment of low-carbon power technologies incentivized under policy without international permit trading. Limiting the amount of carbon permits that could be imported from China to the EU or the US would reduce these effects. ${ }^{12}$

\subsection{Leakage and Aggregate Emissions Reductions}

The emissions reduction constraint imposed in Europe, the US and China in the analysis induce leakage of emissions to non-covered sectors and regions. As noted by Gavard et al. (2011a), capping electricity emissions can lead to leakage of emissions to other sectors in the country applying the sectoral policy (internal leakage). This occurs because the substitution away from coal in the electricity sectors and the associated price decrease leads to greater coal use in other sectors. These effects can be magnified by international permit trading if the export of permits leads to larger increases in the electricity price.

Here, over the 2020-2030 time period, the cumulative emissions reduction constraint imposed in the US-China case is 13 billion tons in the US and 22.1 billion tons in China. In the CHN-ETS

\footnotetext{
${ }^{12}$ Given the fact that Chinese electricity production is nearly three times that in Europe or twice that in the US in 2030, a similar change in absolute values is proportionally more significant in Europe or the US than in China.
} 
case, cumulative internal leakage in China over the 2020-2030 period is 0.89 billion tons of $\mathrm{CO}_{2}$, which increases to 1.18 billion tons of $\mathrm{CO}_{2}$ if there is unlimited trade in permits (see Table 4a). Internal leakage is reduced to 1.06 billion tons when there is a limit on the quantity of permits that the US can import from China. This reduction is because Chinese carbon and electricity prices are lower in the US-CHN-LIMIT scenario than in the US-CHN-TRADE case. In the US, leakage to the rest of the economy is negative. This result is because the increased prices for electricity and energy-intensive commodities reduce output elsewhere, which dominated the impact of substitution towards coal in sectors not covered by the emissions cap.

Table 4a. Cumulative leakage and emissions reductions relative to the NO-POLICY scenario for the time period 2020-2030 (billion $\mathrm{tCO}_{2}$ ).

\begin{tabular}{lcccc}
\hline & US-ETS & CHN-ETS & US-CHN-TRADE & $\begin{array}{c}\text { US- } \\
\text { CHN- } \\
\text { LIMIT }\end{array}$ \\
\hline Leakage to uncovered sectors in China & 0.03 & 0.89 & 1.18 & 1.06 \\
Leakage to uncovered sectors in the US & -0.13 & 0.00 & -0.05 & -0.09 \\
Leakage to the Rest of the World & 1.76 & 1.35 & 2.61 & 2.87 \\
Total Leakage & 1.66 & 2.24 & 3.74 & 3.84 \\
Global Emissions Reduction & 10.90 & 19.70 & 31.27 & 31.18 \\
\hline
\end{tabular}

If international leakage (i.e., leakage to countries without emissions constraints in our simulations) is also taken into account, aggregate leakage is $3 \%$ smaller if carbon trading is not limited than if it is (leakage is 3.74 billion tons of $\mathrm{CO}_{2}$ in the US-CHN-TRADE scenario compared to 3.84 billion tons of $\mathrm{CO}_{2}$ for US-CHN-LIMIT). This result is driven by the impact of the US carbon price change on the rest of the world. However this effect is small (the difference in global emissions reduction between the unlimited and limited trading scenarios is smaller than $0.3 \%)$.

In the case of carbon trading between the EU and China, we observe comparable results (see Table 4b). Carbon leakage to the rest of the economy in China is smaller when there is a limit on the amount of emissions permits that can be exported to the EU (it is 0.98 billion $\mathrm{tCO}_{2}$ in the EUCHN-LIMIT scenario compared to 1.04 billion $\mathrm{tCO}_{2}$ in the EU-CHN-TRADE scenario). As for the US, there is negative internal leakage in the EU due to the carbon policy increasing costs throughout the economy. International leakage is $8.4 \%$ higher under limited carbon trading than under unlimited trading. In aggregate the effect on international emissions dominates the domestic leakage effect and global emissions reduction are higher in the unlimited trading scenario, although the difference is again small $(0.7 \%)$.

In the EU-US-CHN-TRADE case, we estimate total leakage and global emissions reductions to be, respectively, 4.91 and 43.22 billion $\mathrm{tCO}_{2}$. We also estimate that leakage to uncovered sectors in China is 1.28 billion $\mathrm{tCO}_{2}$, which is larger than in the case of bilateral markets due to the higher carbon price reported in section 3.1. 
Table 4b. Cumulative leakage and emissions reductions relative to the NO-POLICY scenario for the time period 2015-2030 (billion $\mathrm{tCO}_{2}$ ).

\begin{tabular}{lcccc}
\hline & EU-ETS & CHN-ETS & EU-CHN-TRADE & $\begin{array}{c}\text { EU- } \\
\text { CHN- } \\
\text { LIMIT }\end{array}$ \\
\hline Leakage to uncovered sectors in China & 0.02 & 0.89 & 1.04 & 0.98 \\
Leakage to uncovered sectors in the EU & -0.15 & 0.00 & -0.10 & -0.12 \\
Leakage to the Rest of the World & 1.59 & 1.35 & 2.73 & 2.96 \\
Total Leakage & 1.46 & 2.24 & 3.67 & 3.82 \\
Global Emissions Reduction & 7.03 & 19.70 & 29.94 & 29.74 \\
\hline
\end{tabular}

\subsection{Welfare Impacts}

The welfare impact of sectoral trading is driven by two effects. On the one hand, trade in carbon permits induces financial transfers from the developed to the developing region (transfer effect). On the other hand, the constraint on the developing country electricity sector makes electricity more expensive, which causes a decrease in aggregate output (general equilibrium effect). Gavard et al. (2011a) show that unlimited sectoral trading improves welfare in developed regions but might decrease it in developing regions. This is driven by the constraint imposed in the developed region being more stringent than the constraint imposed in China. As such, the general equilibrium effect dominates the transfer effect in developing regions when there is sectoral trading. As a consequence, while sharing the carbon constraint improves welfare in the developed country by lowering the cost of its domestic climate policy, this is not necessarily so in the developing country.

As noted in section 2, modeling limited sectoral trading by introducing a trade certificate system requires making a choice regarding the allocation of the revenue from the certificates, which influences welfare in each region. For the welfare analysis, we consider separate cases where the revenue is allocated to China or to the EU or US.

Table 5 reports welfare changes for the policy scenarios considered relative to the NOPOLICY scenario. Table $6 \mathbf{a}$ and $\mathbf{6 b}$ report welfare changes for the US-CHN-LIMIT and EUCHN-LIMIT scenarios with alternative values of $\alpha$, and alternative certificate rent allocations.

Table 5. 2030 Welfare changes relative to the NO-POLICY Scenario (percent).

\begin{tabular}{lccc}
\hline Scenarios & In China & In the US & In the EU \\
\hline CHN-ETS & -0.62 & -0.01 & 0.01 \\
US-ETS & 0.00 & -0.38 & 0.03 \\
EU-ETS & 0.00 & 0.00 & -0.30 \\
US-CHN-TRADE & -0.70 & -0.22 & 0.03 \\
EU-CHN-TRADE & -0.67 & -0.01 & -0.20 \\
EU-US-CHN-TRADE & -0.71 & -0.26 & -0.21 \\
\hline
\end{tabular}


In the CHN-ETS and the US-ETS scenarios, the welfare changes compared to the NOPOLICY scenario (-0.62\% in China in the CHN-ETS scenario, $-0.38 \%$ in the US in the US-ETS case) are driven by the constraints on emissions in each region. Under unlimited sectoral trading (US-CHN-TRADE), the US is better off but China is worse off, as the general equilibrium effect dominates the revenue effect. Unlimited trading of carbon permits is not welfare improving for China as the carbon market only covers parts of the Chinese and US economies and the revenue that China gains from selling emissions permits does not compensate for the welfare loss associated with sharing a tighter emissions constraint with the United States. Comparable results are observed for the EU-CHN-TRADE scenario. In the case of a trilateral market, all regions are worse off than in the bilateral markets scenario due to the fact that the common carbon price is higher (as reported in section 3.1).

Table 6a. 2030 welfare changes in the US-CHN-LIMIT scenario relative to the NO-POLICY scenario for alternative values of $\alpha$ (percent).

\begin{tabular}{lccccc}
\hline Scenarios & \multicolumn{2}{c}{ In China } & & \multicolumn{2}{c}{ In the US } \\
\hline & $\begin{array}{c}\text { Rent to } \\
\text { China }\end{array}$ & $\begin{array}{c}\text { Rent to the } \\
\text { US }\end{array}$ & & $\begin{array}{c}\text { Rent to } \\
\text { China }\end{array}$ & $\begin{array}{c}\text { Rent to the } \\
\text { US }\end{array}$ \\
\cline { 2 - 3 } \cline { 6 - 7 } & -0.63 & -0.70 & & -0.24 & -0.21 \\
US-CHN-LIMIT, $\alpha=0.2$ & -0.58 & -0.68 & & -0.28 & -0.23 \\
US-CHN-LIMIT, $\alpha=0.15$ & -0.56 & -0.67 & & -0.32 & -0.27 \\
US-CHN-LIMIT, $\alpha=0.1$ & -0.57 & -0.65 & & -0.35 & -0.32 \\
\hline US-CHN-LIMIT, $\alpha=0.05$ & & & &
\end{tabular}

Under limited sectoral trading, welfare changes depend on the allocation of certificate revenue. For obvious reasons, welfare is higher in China if it receives the revenue than if certificate revenue is allocated to the US or the EU. For example, for $\alpha=0.15$, welfare decreases by $0.58 \%$ in China if certificate revenue goes to this country, but it decreases by $0.68 \%$ if the revenue is allocated to the US. Similarly, the US or the EU is better off if households in these regions are endowed with the certificates. The welfare change as a function of the limit $\alpha$ depends on several factors. On the one hand, the differences in the carbon constraints and the general equilibrium effects associated with sharing them tend to make the developed region better off and China worse off. That is why welfare in the US or the EU is improved in all carbon trading scenarios, compared to when these regions implement isolated ETSs. On the other hand, the financial transfer associated with the certificate rent may compensate this if the rent is allocated to China. That is why we observe that Chinese welfare is improved for any limit $\alpha$ equal to or smaller than 0.15 in the US-China case and 0.1 in the EU-China case. Such limits correspond to pareto-superior situations compared to the case in which China does not trade carbon permits internationally. 
Table 6b. 2030 welfare changes in the EU-CHN-LIMIT scenarios relative to the NO-POLICY scenario for alternative values of $\alpha$ (percent).

\begin{tabular}{llccccc}
\hline Scenarios & \multicolumn{2}{c}{ In China } & & \multicolumn{2}{c}{ In the EU } \\
\cline { 2 - 3 } & $\begin{array}{c}\text { Rent to } \\
\text { China }\end{array}$ & $\begin{array}{c}\text { Rent to the } \\
\text { EU }\end{array}$ & & $\begin{array}{c}\text { Rent to } \\
\text { China }\end{array}$ & $\begin{array}{c}\text { Rent to the } \\
\text { EU }\end{array}$ \\
\cline { 2 - 3 } EU-CHN-LIMIT, $\alpha=0.2$ & -0.65 & -0.66 & & -0.21 & -0.20 \\
EU-CHN-LIMIT, $\alpha=0.15$ & -0.63 & -0.65 & & -0.23 & -0.22 \\
EU-CHN-LIMIT, $\alpha=0.1$ & -0.62 & -0.64 & & -0.25 & -0.23 \\
EU-CHN-LIMIT, $\alpha=0.05$ & -0.61 & -0.63 & & -0.27 & -0.26 \\
\hline
\end{tabular}

We note that the relationship between welfare in China and the limit on international permit trade is non-linear function. For example, with permit trading between China and the US, China is better off for $\alpha=0.1$ than for $\alpha=0.05$. This is because the financial transfers associated with the certificate rent depend on the certificate price (i.e., the carbon price difference between the two countries) and the volume of transfers. While the certificate price decreases with $\alpha$, the volume of permits increases with the limit. As a consequence, financial transfers associated with the rent are not necessarily a monotonic function of $\alpha$ (see Table 7).

Table 7. Price of certificates and corresponding rent in the US-CHN-LIMIT scenario in 2030.

\begin{tabular}{lcc}
\hline & $\begin{array}{c}\text { Certificate Price } \\
(\mathbf{\$})\end{array}$ & $\begin{array}{c}\text { Rent (\$ } \\
\text { million) }\end{array}$ \\
\hline $\begin{array}{l}\text { US-CHN-LIMIT, } \\
\alpha=0.05\end{array}$ & 45.9 & 8031 \\
$\begin{array}{l}\text { US-CHN-LIMIT, } \\
\alpha=0.1\end{array}$ & 31.3 & 8742 \\
$\begin{array}{l}\text { US-CHN-LIMIT, } \\
\alpha=0.15\end{array}$ & 19.4 & 7456 \\
$\begin{array}{l}\text { US-CHN-LIMIT, } \\
\alpha=0.2\end{array}$ & 9.4 & 4610 \\
\begin{tabular}{c} 
US-CHN-TRADE \\
\hline
\end{tabular} & 0 & 0 \\
\hline
\end{tabular}

Table 8 summarizes changes in electricity prices, aggregate output, net exports and the terms of trade in China as a consequence of carbon trading with the EU or the US. We observe that the electricity price in China in 2030 rises by $16 \%$ in the US-CHN-TRADE scenario and by $1.8 \%$ in the US-CHN-LIMIT scenario $(\alpha=0.1)$ relative to the CHN-ETS scenario. The aggregate output of Chinese economic sectors decreases by $0.10 \%$ in the US-CHN-TRADE scenario and $0.05 \%$ in the US-CHN-LIMIT scenario. Exports decrease by $18 \%$ in the US-CHN-TRADE scenario and by $4.9 \%$ in the US-CHN-LIMIT scenario but the terms of trade increase by $0.10 \%$ in the USCHN-TRADE scenario and by $0.02 \%$ in the US-CHN-LIMIT scenario.

In the case of trading with Europe, these figures are more moderate: the electricity price in China increases by $7.2 \%$ under unlimited carbon trading, compared to $2.9 \%$ under limited trading. While Chinese net exports are reduced in both cases (by 6.7\% in the EU-CHN-TRADE 
scenario and by $2.2 \%$ in the EU-CHN-LIMIT scenario) the terms-of-trade is nearly unchanged (it increases by $0.03 \%$ in the EU-CHN-TRADE scenario, and by less than $0.005 \%$ in the EU-CHNLIMIT case).

Table 8. Change in electricity price, aggregate output, next exports and the terms of trade in China in 2030, relative to the China-ETS scenario (percent).

\begin{tabular}{lcccc}
\hline Scenarios & $\begin{array}{c}\text { Change in } \\
\text { Electricity } \\
\text { Price }\end{array}$ & $\begin{array}{c}\text { Change in } \\
\text { Aggregate } \\
\text { Output }\end{array}$ & $\begin{array}{c}\text { Change in } \\
\text { Net Exports }\end{array}$ & $\begin{array}{c}\text { Change in the } \\
\text { Terms of } \\
\text { Trade }\end{array}$ \\
\hline EU-CHN-TRADE & +7.20 & -0.05 & -6.64 & +0.03 \\
EU-CHN-LIMIT & +2.88 & -0.03 & -2.20 & +0.00 \\
\hline US-CHN-TRADE & +16.36 & -0.10 & -17.99 & +0.10 \\
US-CHN-LIMIT & +1.80 & -0.05 & -4.92 & +0.02 \\
\hline EU-US-CHN-TRADE & +14.59 & -0.11 & -26.56 & +0.14 \\
\hline
\end{tabular}

\section{CONCLUSIONS}

In the Paris Agreement adopted at the $21^{\text {st }} \mathrm{COP}$ of the UNFCCC, particular attention has been given to international cooperation and support to developing countries to address climate change. As carbon markets are being implemented in many regions of the world, the question of whether linkages between them could contribute to this support is relevant. In earlier sessions of international climate negotiations, new market mechanisms such as sectoral trading were proposed. We analyze such a coupling mechanism between emissions trading schemes covering the electricity and energy intensive sectors of a developed and a developing country. As previous studies show that such unlimited carbon trading could lead to a welfare loss in the developing country involved, we limit the volume of permits that can be traded between the two countries or regions by introducing a trade certificate system. Our simulations consider both EU-China and US-China trading cases. We also include the case of a trilateral carbon market.

We find that, while carbon prices in developing and developed regions equalize when trade is unrestricted, the introduction of a limit on the volume traded induces a carbon price difference between the two regions. In the US-China case, carbon prices equalize at $\$ 23.9 / \mathrm{tCO}_{2}$ under unlimited carbon trading. When the amount of Chinese carbon permits imported by the US cannot exceed $10 \%$ of the number of permits issued under a hypothetical US ETS, the carbon price is $\$ 50.6 / \mathrm{tCO}_{2}$ in the US and $\$ 19.3 / \mathrm{tCO}_{2}$ in China. The change in the US carbon price represents a $37 \%$ decrease compared to $70 \%$ when there is no limit. If the amount of Chinese permits that is accepted in the ETS is $5 \%$ or $20 \%$ of the number of US allowances, the US carbon price is respectively $\$ 64.4 / \mathrm{tCO}_{2}$ and $\$ 30.4 / \mathrm{tCO}_{2}$. In the EU-China case, the European carbon price is reduced by $59 \%$ under unlimited carbon trading with China, compared to $31 \%$ if the volume of Chinese permits imported by the EU is no more than $10 \%$ of the number of European allowances issued under the EU ETS cap. 
We observe that, while unlimited sectoral trading enhances adoption of low-carbon technologies induced by the emissions reduction constraint in the Chinese electricity sector, this effect is diminished under limited sectoral trading. Low carbon technologies represent $36.9 \%$ of a total of 32.6 EJ of electricity produced in China in 2030 under a national ETS. Under unlimited sectoral trading with the US ETS, the amount of electricity from low carbon technologies in China increases by $0.38 \mathrm{EJ}$ but the total amount of electricity produced in this country decreases by $3 \%(0.06 \mathrm{EJ})$. If there is a limit on the amount of permits traded, electricity from low carbon technologies represents $12.4 \mathrm{EJ}$, which is $37.6 \%$ of the total amount of electricity generated in China. In the US, while unlimited sectoral trading partially reverses the changes in the electricity sector induced by the US carbon market, a limit on this mechanism moderates this effect. If no emissions trading is allowed between the US and China, low carbon electricity in the US is 6.38 EJ in 2030, compared to 6.18 EJ with limited sectoral trading, and 5.92 EJ under unlimited sectoral trading. In the EU-China case, the share of low-carbon technologies in Chinese power generation increases from $12.04 \mathrm{EJ}$ when there is no carbon trading with the EU to $12.10 \mathrm{EJ}$ when the exchange of emissions permits is limited, and 12.20 EJ when it is not. But the total amount of power produced in this country is reduced by $0.16 \mathrm{EJ}$ in the case of unlimited carbon trading and 0.06EJ if a limit is set on the exports of carbon permits to Europe. In the EU, the share of low-carbon technologies is reduced from 57.4\% if the EU ETS does not accept carbon allowances from China to $55.2 \%$ if permit imports are limited, and $53 \%$ if permit imports are unlimited.

Regarding aggregate emissions, we observe that leakage to the rest of the Chinese economy is lower when a limit is set on the amount of permits that can be traded than without it, due to the fact that the carbon price in China is higher in the absence of limit. On the other hand, international leakage is higher when exports of carbon permit from China to the EU or the US are limited. In aggregate, the international effect more than offsets the domestic impact and global emissions reductions are higher under unlimited carbon trading than in the other scenarios. The difference in leakage under the limited and unlimited carbon trading scenarios is, however, less than $1 \%$.

Welfare changes in the regions involved depend on the way the revenue from the certificates is allocated. China is better off if it receives the revenue than if the revenue is allocated to the EU or the US. China suffers a consumption loss in the case of unlimited carbon trading with the EU or the US. On the contrary, if the export of emission permits is limited, it is possible to find a limit that makes both regions better off or at least one region as well off and the other better off relative to when there is no international trade in emissions permits. In the analysis, this Pareto superior situation is reached when the volume of Chinese permits imported to Europe cannot exceed $10 \%$ of the volume of EU allowances defined by the EU ETS cap. This threshold is $15 \%$ in the case of carbon trading between China and the US.

To conclude, sectoral trading would allow some developing countries to participate in the carbon market set by developed countries. If a limit is set on the amount of permits that can be traded, such a mechanism would not decrease the carbon price in the developed country as much 
as when there is no limit. As a consequence, it would not reverse the emissions reductions initiated in the developed country, and in particular in its power sector, as much as unlimited trading would. In terms of aggregate emissions reductions, the difference between the limited and unlimited carbon trading scenarios is minor. Finally, we observe that, if the revenue from the certificates is allocated to the developing country's households, it is possible to find a limit that makes both regions involved better off compared to the case in which no trading is allowed between the two regions.

\section{Acknowledgments}

The authors wish to thank Henry D. Jacoby for helpful comments and suggestions. The work was completed while Claire Gavard was visiting the Joint Program on the Science and Policy of Global Change. The MIT EPPA model development is supported by a consortium of industrial and foundation sponsors and Federal awards, including the U.S. Department of Energy, Office of Science under DE-FG02-94ER61937 and the U.S. Environmental Protection Agency under XA83600001-1 (for a complete list see http://globalchange.mit.edu/sponsors/current.html). The funding sources had no involvement in the conduct of the research and/or preparation of the article.

\section{REFERENCES}

Armington, P.S., 1969: A Theory of Demand for Products Distinguished by Place of Production. IMF Staff Papers 16, 159-76.

Baron, R., I. Barnsley and J. Ellis, 2008: Options for Integrating Sectoral Approaches into the UNFCCC. OECD, November, $41 \mathrm{p}$.

Baron, R., B. Buchner and J. Ellis, 2009: Sectoral Approaches and the Carbon Market, OECD, June, $51 \mathrm{p}$.

Bradley, R., B.C. Staley, T. Herzog, J. Pershing and K.A. Baumert, 2007: Slicing the Pie: SectorBased Approaches to International Climate Agreements. World Resources Institute Report, December, $55 \mathrm{p}$.

Caron, J., S. Rausch, and N. Winchester, 2015. Leakage from sub-national climate policy: The case of California's cap-and-trade program. The Energy Journal, 36(2).

CCAP [Center for Clean Air Policy], 2008: A Bottom-Up Sector-Based Approach to the Post2012 Climate Change Policy Architecture, June, 33 p.

CCAP, 2010: Global Sectoral Study: Final Report, May, 57 p.

Chen, Y., A. L. Liu, B. F. Hobbs, 2011. Economics and Emissions Implications of Load-Based, Source-Based, and First-Seller Emissions Trading Programs under California AB32. Operations Research, 59 (3): 696-712.

EPA [Environmental Protection Agency], 2015. Carbon Pollution Emission Guidelines for Existing Stationary Sources: Electric Utility Generating Units. 40 CFR Part 60, October.

Ellerman, A.D., B. K. Buchner, 2007. The European Union Emissions Trading Scheme: Origins, Allocation, and Early Results. Review of Environmental Economics and Policy, 1 (1): 66-87. 
Ellerman, A.D., B. K. Buchner, 2008. Over-Allocation or Abatement? A Preliminary Analysis of the EU ETS Based on the 2005-06 Emissions Data. Environmental and Resource Economics, 41: 267-287.

EU [European Union], 2004. Directive 2004/101/EC of the European Parliament and of the Council of 27 October 2004.

EU, 2008. Directive 2008/10/EC of the European Parliament and of the Council of 19 November 2008 amending Directive 2003/87/EC so as to include aviation activities in the scheme for greenhouse gas emission allowance trading within the Community, November.

EU, 2009. Commission staff working document accompanying the Communication from the Commission to the European Parliament, the Council, the European Economic and social Committee and the Committee of the Regions, Stepping up international climate finance: A European blueprint for the Copenhagen deal \{COM(2009) 475\}. Brussels, SEC(2009) $1172 / 2$, September.

EU, 2010. Communication from the Commission to the European Parliament, the Council, the European Economic and Social Committee and the Committee of the Regions, Analysis of option to move beyond $20 \%$ greenhouse gas emission reductions and assessing the risk of carbon leakage $\{\operatorname{COM}(2010) 265$ final $\}$. Brussels, SEC(2010) 650, May.

EU, 2011. Communication from the Commission to the European Parliament, the Council, the European Economic and Social Committee and the Committee of the Regions, Energy Roadmap 2050 \{COM(2011) 885 final $\}$. Brussels, December.

EU, 2014. Communication from the Commission to the European Parliament and the Council, Energy Efficiency and its contribution to energy security and the 2030 Framework for climate and energy policy $\{\mathrm{COM}(2014) 520$ final $\}$. Brussels, July.

Gavard C., N. Winchester, H. Jacoby and S. Paltsev, 2011a. What to Expect from Sectoral Trading:a U.S.-China Example. Climate Change Economics, 2(1): 9-27; MIT Joint Program Reprint 2011-16 (http://globalchange.mit.edu/files/document/MITJPSPGC_Reprint_1116.pdf).

Gavard C., N. Winchester, H. Jacoby and S. Paltsev, 2011b: Sectoral Trading between the EU ETS and Emerging Countries. MIT JPSPGC Report 193, Appendix A, February, 9 p. (http://globalchange.mit.edu/files/document/MITJPSPGC_Rpt193.pdf).

Hamdi-Cherif, M., C. Guivarch and P. Quirion, 2010: Sectoral Targets for Developing Countries: Combining "Common but Differentiated Responsibilities" with "Meaningful Participation”. FEEM Nota di Lavoro 37.2010.

Hepburn, C., M. Grubb, K. Neuhoff, F. Matthes and M. Tse, 2006. Auctioning of EU ETS phase II allowances: how and why? Climate Policy, 6(1): 137-160.

ICAP [International Carbon Action Partnership], 2016: EU Emissions Trading System (EU ETS), March.

ICC [International Chamber of Commerce], 2008: International Sectoral Approaches (ISA) in the UNFCCC post 2010 framework: ICC perspectives, Discussion Paper 213-62, November.

IEA [International Energy Agency], 2005a: Exploring Options for Sectoral Crediting Mechanisms. 44 p.

IEA, 2005b: Sectoral Crediting Mechanisms: An initial Assessment of Electricity and Aluminium. November, $36 \mathrm{p}$.

IEA, 2006a: Sectoral Approaches to GHG Mitigation: Scenarios for Integration. 22 p. 
IEA, 2006b: Sectoral Crediting Mechanisms for Greenhouse Gas Mitigation: Institutional and Operational Issues. May, $34 \mathrm{p}$.

IEA, 2007: Sectoral Approaches to Greenhouse Gas Mitigation: Exploring Issues for Heavy Industry. $76 \mathrm{p}$.

IEA, 2009b: Sectoral Approaches in Electricity, Building Bridges to a Safe Climate. 186 p.

Lecocq, F. and P. Ambrosi, 2007: The Clean Development Mechanism: History, Status and Prospects. J. Review of Environmental Economics and Policy, 1(1): 134-151.

Malina, R., D. McConnachie, N. Winchester, C. Wollersheim, S.Paltsev and I.A. Waitz, 2012: The impact of the European Union Emissions Trading Scheme on US aviation. Journal of Air Transport Management, 19: 36-41.

Massetti, E., M. Tavoni, 2012: A developing Asia emission trading scheme (Asia ETS). Energy Economics, 34(3): S436-S443.

Martin, R., M. Muûls, L. B. de Preux, U. J. Wagner, 2014. Industry Compensation under Relocation Risk : A Firm-Level Analysis of the EU Emissions Trading Scheme. American Economic Review, 104(8).

Narayanan, B.G. and T.L. Walmsley (eds), 2008: Global Trade, Assistance, and Production: The GTAP 7 Data Base, Center for Global Trade Analysis, Purdue University.

Paltsev, S., J. M. Reilly, H. D. Jacoby, J. F. Morris, 2009: The cost of climate policy in the United States. Energy Economics, 31(2): S235-S243.

Paltsev S., J. Reilly, H.D. Jacoby, R.S. Eckaus, J. McFarland, M. Sarofim, M. Asadoorian and M.Babiker, 2005: The MIT Emissions Prediction and Policy Analysis (EPPA) Model: Version 4. MIT JPSPGC Report 125, 72 p. (http://globalchange.mit.edu/files/document/MITJPSPGC_Rpt125.pdf).

Rutherford T., 1995: Extension of GAMS for Complementary Problems Arising in Applied Economic Analysis. Journal of Economics Dynamics and Control, 19(8): 1299-324.

Sawa, A., 2010: Sectoral Approaches to a Post-Kyoto International Climate Policy Framework. In: Post-Kyoto International Climate Policy, J.E. Aldy and R.N. Stavins (eds.), Cambridge University Press: Cambridge, UK, Chapter 7, pp. 201-239.

Schneider, L., 2007: Is the CDM Fulfilling its Environmental and Sustainable Development Objectives ? An Evaluation of the CDM and Options for Improvement. Öko-Institut, Report for the WWF.

Schneider, L. and M. Cames, 2009a: A Framework for a Sectoral Crediting Mechanism in a Post-2012 Climate Regime. Öko-Institut, Report for the Global Wind Energy Council.

Schneider L., M. Cames, 2009b: Sectoral Crediting Mechanism Design. Öko-Institut, Results of a Study Commissioned by the Global Wind Energy Council (GWEC).

Sterk, W., 2008: From Clean Development Mechanism to Sectoral Crediting Approaches_Way Forward or Wrong Turn, JIKO Policy Paper 1.

Sue Wing, I. and M. Kolodziej, 2008. The Regional Greenhouse Gas Initiative: Emissions Leakage and the Effectiveness of Interstate Border Adjustments. Regulatory Policy Program Working Paper RPP-2008-03, John F. Kennedy School of Government, Harvard University.

Tirole, J., 2009: Politique Climatique: une Nouvelle Architecture Internationale, Conseil d'Analyse Economique. Conseil d'analyse économique, October, 360 p. 
Trotignon, R., G. Simonet, V. Boutueil, 2011: Panorama: Carbon markets and prices around the world in 2011. In: Climate Economics in Progress 2011, C. De Perthuis and P.-A. Jouvet (eds.), Economica, Chapter 1, pp. 10-24.

UN [United Nations], 1998. Kyoto Protocol to the United Nations Framework Convention on Climate Change.

UN, 2009. Copenhagen Accord, FCCC/CP/2009/L.7, 18 December.

White House, 2015: U.S.-China Joint Presidential Statement on Climate Change, Office of the Press Secretary, 25 September. https://www.whitehouse.gov/the-press-office/2015/09/25/uschina-joint-presidential-statement-climate-change

White House, 2015: U.S.-China Joint Announcement on Climate Change, Office of the Press

Secretary, 12 November. https://www.whitehouse.gov/the-press-office/2014/11/11/us-chinajoint-announcement-climate-change

Zhang, X., V.J.Karplus, T. Qi, D. Zhang and J. He, 2014: Carbon Emissions in China: How far can new efforts bend the curve? MITJPSPGC Report 267, February, 25p.

\section{APPENDIX}

\section{Aviation emissions, CDM and JI credits in the EU ETS}

Initial legislation for extending the EU ETS to aviation aimed to include, from 2012 onwards, emissions from all flights departing or landing at an EU airport (including flights to and from non-EU countries). However, due to political pressure from several non-EU countries, the scheme was amended so that it currently only applies to flights within Europe, including the countries of the European Economic Area (EEA) and European Free Trade Association space (EFTA). ${ }^{13}$ The cap set on European aviation is 210 million tons each year from 2013 onwards. Given the high growth rate predicted for the sector and the high cost of abating aviation emissions, the aviation sector will likely purchase permits from the general EU ETS (Malina et al., 2012).

The impact of demand for permits by the aviation industry may be compensated by the use of CDM and JI credits. ${ }^{14}$ For the time period 2008-2020, the limit of CDM and JI credits accepted for compliance in the EU ETS is 1.7 billion $\mathrm{tCO}_{2}$. Some organizations estimated that 1.6 to 1.7 billion tons of offsets could be used in phase II and III combined (ICAP, 2016). For Phase IV, the 2030 emissions reduction objective shall be achieved domestically, ie without the use of international credits.

If we consider that aviation emissions grow at an annual rate of $3 \%, \mathrm{CDM} / \mathrm{JI}$ credits do not fully compensate for the allowances that the aviation sector will have to buy on the general ETS

\footnotetext{
13 The European Economic Area comprises the countries of the EU, plus Iceland, Liechtenstein and Norway. The members of the European Free Trade Association are Liechtenstein, Norway, Iceland and Switzerland.

${ }^{14}$ All projects are accepted except nuclear energy projects, afforestation and reforestation activities, and, from 2013 onwards, projects involving the destruction of industrial gases. Credits from large hydropower projects are subject to conditions.
} 
to cover its emissions above the aviation ETS cap. In the analysis, we hence reduce the general EU ETS cap by all aviation emissions above the aviation cap that are not covered by the estimated CDM and JI credits available for compliance in the EU ETS. This simplification does not take account of the marginal abatement cost curve for CDM and JI projects, but it allows the specification of a cap on emissions net of demand for permits by the aviation industry and use of CDM and JI credits. In practice, non-aviation and aviation sectors may purchase CDM and JI credits. As a net cap is used in the modeling framework, the results do not depend on which sectors use the CDM and JI credits. 